ISSN: 2224-0616

Int. J. Agril. Res. Innov. Tech. 11(1): 17-25, June 2021

DOI: https://doi.org/10.3329/ijarit.v11i1.54462
OPEN 2 ACCESS

Available online at https://ijarit.webs.com https://www.banglajol.info/index.php/IJARIT

\title{
What determines Enset (Ensete ventricosum) production and its contribution to household income? Empirical evidence from Ethiopia
}

\author{
Ejigu Mulatu
}

Received 7 February 2021, Revised 28 April 2021, Accepted 23 June 2021, Published online 30 June 2021

\begin{abstract}
A B S T R A C T
Enset production in Ethiopia is seemingly limited to only consumption-based production and most of producers supplied small amounts of products to the market. This study was conducted with main objective of assessing factors affecting market participation of enset producers in Chena district in southwestern Ethiopia. Two-stage sampling technique was employed to select 101 representative enset producer households. Both primary and secondary data sources were used to gather necessary data for attaining specific objectives of the study. Both descriptive statistics and econometric model were used to analyze the collected data. A Heckman two stage model was employed to analyze the factors affecting households' decision in market participation in sale of enset products and the amount of gross income earned. Econometric model analysis result showed that; sex of household head, education level, livestock owned, a distance from nearest market center, enset plantation size, and transport access were found to be significant in affecting the probability of market participation decision. In addition, education level, family size, distance from market center, enset plantation, and transport access affected the amount of gross income earned from sale of different enset products. The result suggests the need for stakeholders' involvement to enable market-oriented production of crop to encourage farmers for better crop production and market supply to have increased amount of income and proper utilization of the crop.
\end{abstract}

Keywords: Determinants, Enset products, Producers, Gross income, Heckman two stage.

Researcher, Dept. of Farm Management and Mechanization, Southern Agricultural Research Institute, Hawassa, Ethiopia.

*Corresponding author’s email: ejigum61@gmail.com (Ejigu Mulatu)

Cite this article as: Mulatu, E. 2021. What determines Enset (Ensete ventricosum) production and its contribution to household income? Empirical evidence from Ethiopia. Int. J. Agril. Res. Innov. Tech. 11(1): 1725. https://doi.org/10.3329/ijarit.v11i1.54462

\section{Introduction}

In Ethiopia population of 79.3 million living in rural area being employed in agriculture (FAO, 2015), agriculture is the main driver for growth and long-term food security as it contributes on average $44.18 \%$ share to GDP and $29.31 \%$ share for GDP growth from the year 2007-08 up to 2014-15 fiscal year (NBE, 2014-15). Enset based farming is an indigenous agricultural system and more than $20 \%$ of the population depend on enset for food, feed and fiber in the country. Due to its drought tolerance, enset plant is regarded as a priority crop in Ethiopia, where it makes a major contribution to the food security of the country (Mohamed and Tariku, 2012). According to some reports, for instance, Nuri et al. (2016) revealed, enset crop is produced as a staple, costaple food, and represent a potential pathway to move out of poverty for many smallholders in Southern and South Western Ethiopia.
Enset is a multi-purpose and multi-year crop with over $80 \%$ of its production in the country is covered by the south and southwestern parts of the country. Enset is one of the indigenous root crops cultivated as traditional staple food crop and its' cultivation reaches about 65 percent of the total crop production in southern nation nationalities and people's regional state of Ethiopia (Birmeta et al., 2004). During 2014-15 agricultural production year in Ethiopia, 345093 tone of kocho was supplied to market from Southern Ethiopia (CSA, 2015).

Market participation and commercialization involves the integration of agricultural product or a household into a market economy. This integration may be expressed by an increased financial trade value or by the proportion of the sale to the total income obtained. The success of product commercialization can be determined by 
factors external to small-scale farmers, including infrastructure, level of urbanization, technological change, and demand for the product as well as farm-level factors such as landholding, extent of land use diversification, level of input use, and intensity of management. Therefore, the commercialization of a product can be stimulated or discouraged by factors ranging from household characteristics to broader institutional and policy environments (Endalamaw et al., 2013).

The main problem in Enset producer household in Ethiopia is the inability to produce at a commercial scale and the loss of its product during processing, the improper storage of the final produce before consumption. In addition, enset production is highly affected by diseases, insect pests and vertebrates, the use of backward and inefficient traditional methods and equipment in production, processing and marketing activities, and low attention from existing extension component on protection and promotion of the crop (Mohamed and Tariku, 2012; Yemataw et al., 2017).

Moreover, it is clear observation that enset processing with traditional processing material is not easy task for women where there is no improved technology to do so. Due to this condition, enset production is seemingly limited to consumption purpose and most of farmers sold small amounts of products like kocho, bulla and fiber (Alemayehu, 2018). Traditional or subsistent way of production, lack of improved harvesting, processing and value addition technology and expansion of other crop production let farmers to have little experience of money making from enset production. According to Tessema et al. (2017), different socioeconomic variables such as age of the household head, distance between the farmers' residence and the products market, livestock ownership, family size and area covered by enset were found to be important variables affecting kocho and bulla market participation by enset farmer households. Chena district is one of potential enset producing areas in Kaffa zone as its' farming system is characterized by crop-livestock mixed farming with the two dominant perennial crops, Enset and coffee crops are grown in a friendly association with other crops (CDOARD, 2015). Market imperfections in the area also challenged sustained enset farming and the conservation practices of the enset production. This could be revealed through the existence of thin markets with few buyers and farmers with poor access to market information (Tsehaye and Kebebew, 2006). Despite the facts that enset remained staple crop in the area, little research and development attention have been given so far annoyingly. As such potential of enset for food security and income generation, it has not been fully exploited by smallholder farmers (Belachew et al., 2017). It is required that farmers should produce not merely for home consumption but also should have increased production and market supply with fair price for their product. Despite the importance of the enset crop to farm households, there is absence of study conducted in the district regarding market participation of enset producers. This affected production and productivity of a crop and resulted in lack of relevant information for researchers and policy makers. Thus, this study was needed to assess determinants of market participation of enset producers in Chena district of south-western Ethiopia.

\section{Specific objectives}

- To assess a status of enset production and its contribution to household income

- To identify factors affecting producers' market participation and level of participation in sale of enset products

\section{Research Methodology}

\section{Description of the study area}

The study was conducted in chena district in kaffa zone of southwestern Ethiopia. The district is found at 510 and $785 \mathrm{~km}$ far from Addis Ababa and Hawassa, respectively. The district is located at $07^{\circ} 18^{\prime} 48^{\prime \prime N}$ Latitude and $036^{\circ} 16^{\prime} 25^{\prime \prime} \mathrm{E}$ Longitude and at altitude 2020 masl. It is bordered on the south by the Bench Majji zone, on the northeast by Gimbo, by Bita on the west, by Gewata on the north and on the east by Decha districts in Kaffa zone (Kifle et al., 2015). The district agro ecology is 15\% high land, $80 \%$ midland and $5 \%$ lowland. The district has a minimum temperature of $16^{\circ} \mathrm{C}$ and maximum temperature of $28^{\circ} \mathrm{C}$ with the annual mean rain fall of $1800 \mathrm{~mm}$. The total area coverage of Chena district reaches $901.92 \mathrm{~km}^{2}$ (Kassa et al., 2018). The farming system of the district is characterized by crop-livestock mixed farming with the two dominant perennial crops enset and coffee are grown in a friendly association with other crops. Agriculture forms the major lifeline in the district as major crops grown include coffee, barley, enset, maize, sorghum, teff, faba bean, wheat, common bean and potato (CDOARD, 2015).

\section{Sampling techniques and sample size determination}

To select sample households for this study, twostage sampling was employed. In the first stage, four Kebeles from enset producing kebeles were selected purposively based on their potentials and accessibility in the condition that they represent the district. In the second stage, by 
taking the list of enset producing farmers from each selected Kebeles as a sample frame, 101 representative enset producer households were randomly selected in probability proportion to size of each Kebele's population.

\section{Data sources and methods of collection}

In this study, both primary and secondary data sources were used to gather necessary data regarding the demographic and socio-economic profile of enset producers and situations of enset production and marketing. The structured questionnaire was used to generate the primary data from the selected sample producers. The primary data was collected from the selected sample respondents. In addition, focus group discussions (FGDs) and key informants interview also used to gather necessary information to supplement data collected from selected respondents. Furthermore, secondary data was obtained from published and unpublished documents of different organizations including district office of agriculture and rural development, Non-Governmental Organizations (NGOs), Central Statistical Authority (CSA), and the like.

\section{Data analysis}

The sample respondents' demographic and socioeconomic conditions as well as enset production and marketing situations was computed using descriptive statistics like mean, standard deviations, frequency and percentage. In addition, the potential variables that were hypothesized to influence the farmers' market participation in sale of enset products were tested for statistical difference using t-statistics and Chisquare $\left(\chi^{2}\right)$ tests for continuous and dummy variables respectively. Furthermore, determinants of farmers' market participation in the sale of enset products and amount of gross income got from sale of enset products was analyzed by using Heckman two stage model.

\section{The Heckman two-step procedure}

The preponderance of zero value for a number of the observations in a data set can lead to a number of econometric problems when working with Ordinary Least Squares to estimate the unknown parameters of a regression model (Greene, 2003). One of approach commonly used during this condition is the Tobit Model developed by James Tobin (Tobin, 1958). In the Tobit model censoring is assumed to represent a standard corner solution and this in itself is a restrictive assumption relying. The other option, Cragg (1971) or double-hurdle model, assumes that two separate hurdles must be passed before a positive level of participation can be observed (Wooldridge, 2002). However, the presence of selectivity bias makes Heckman's sample selection model preferable as it works based on the assumption of first hurdle dominance.

This study used two-step Heckman's procedure to estimate determinants of farmers' market participation and the level of participation. The first step of the Heckman's procedure involves estimation of the Probit equation to explain the participation decision and in the second step OLS estimation equation for level of participation is performed by using the selection bias control factor Lambda (predicted inverse Mills ratio) as an additional independent variable as it reflects the effect of all the unmeasured characteristics, which are related to the participation decision.

Participation equation specified using a binary decision model, a random variable Y (dependent variable) takes the value of " 1 " if the household participates in enset products marketing and "o", otherwise. The probability of a household to participate on enset products marketing depends on a vectors of independent variables $\mathrm{X}_{i}$ and a vector of unknown parameters $\beta$. The vector $\mathrm{X}_{i}$ represents household heads demographic, socioeconomic and institutional factors and the model is specified as follows:

$Y_{1 i}^{*}=\beta X_{i}+\varepsilon_{i}, \varepsilon_{i} \sim N(0,1)$

$Y_{i}=\left\{\begin{array}{ll}1 & \text { if } Y_{i}^{*}>0 \\ 0 & \text { if } Y_{i}^{*} \leq 0\end{array}\right)$

Where, $\mathrm{Y}_{1 \mathrm{i}}{ }^{*}$ is a latent (unobservable) variable representing households' separate decision whether or not to participate, $\mathrm{x}_{\mathrm{i}}$ is a vector of independent variables hypothesized to affect household's decision of participation, $\beta$ is a vector of parameters to be estimated; $\varepsilon_{i}$ is the random error term.

In the second step, OLS estimation equation for level of participation is specified as follows:

$Y_{2 i}=\gamma_{0}+\gamma_{i} X_{i}+\mu_{i} \lambda_{i}+\eta_{i}, \eta_{i} \sim N\left(0, \delta^{2}\right)$

Where, $\mathrm{Y}_{2 \mathrm{i}}$ isthe amount of gross income got from sale of enset products in the second step; $\mathrm{X}_{\mathrm{i}}$ are the explanatory variables determining the amount of gross income from sale of enset products; $\gamma_{i}$ are unknown parameters that estimated in the amount of gross income; $\mu_{i}$ is a parameter that shows the impact of selectivity bias on the amount of gross income from sale of enset products ; $\eta$ is the error term. 
Table 1. Summary of definitions of variables and working hypotheses.

\begin{tabular}{|c|c|c|c|c|}
\hline \multirow[t]{2}{*}{ Variables } & \multirow[t]{2}{*}{ Descriptions of variable } & \multirow[t]{2}{*}{ Types } & \multicolumn{2}{|c|}{ Expected Relation } \\
\hline & & & Participation & Intensity \\
\hline \multicolumn{5}{|l|}{ Dependents } \\
\hline MRKTPART & Market participation $($ yes $=1, \mathrm{No}=0$ ) & Dummy & & \\
\hline LEVLPARTC & $\begin{array}{l}\text { Gross income from sale of enset products in } \\
\text { birr }\end{array}$ & Continuous & & \\
\hline \multicolumn{5}{|l|}{ Independents } \\
\hline SEX & Sex of household head (male $=1$, female $=0$ ) & Dummy & + & + \\
\hline AGE & Age of the household head & Continuous & + & + \\
\hline EDUCATION & Education level of household head & Continuous & + & + \\
\hline FAMSIZE & Family size & Continuous & - & - \\
\hline ENSETLAND & Area coverage of enset plantation (ha) & Continuous & + & + \\
\hline LIVESTOCK & Livestock ownership in TLU & Continuous & - & - \\
\hline LANDSIZE & Land size (ha) & Continuous & + & + \\
\hline DISTANCE & Distance to nearest market (Km) & Continuous & - & - \\
\hline EXTENSN & Access to extension service $(\mathrm{yes}=1, \mathrm{No}=0)$ & Dummy & + & + \\
\hline MRKTINFO & Access to market information $(\mathrm{yes}=1, \mathrm{No}=0$ ) & Dummy & + & \\
\hline TRPRTACCES & Access to transport (yes $=1, \mathrm{No}=0$ ) & Dummy & + & + \\
\hline
\end{tabular}

\section{Results and Discussion}

\section{Sample respondents' characteristics}

The Mean age of the total sample was 45.72 years. Mean age of market participant group was 47.53 years $(\mathrm{SD}=10.70)$. By comparison, nonparticipant group was associated with numerically lower age of $42.59(\mathrm{SD}=8.81)$. The result of independent sample t-test showed that, there was statistically significant difference between mean of two groups at $5 \%$ level of significance. The Mean education level of the total sample respondent was 3.27 years. Mean education level of market participant group was 4.375 years $(\mathrm{SD}=3.917)$. By comparison, nonparticipant group was associated with numerically lower mean education level of 1.37 years $(\mathrm{SD}=2.19)$ and there was statistically significant mean difference between two groups at $1 \%$ level of significance.

The Mean family size of the sample respondents was 7.46. Mean family size of market participant group was 7.34 $(\mathrm{SD}=2.15)$. By comparison, nonparticipant group was associated with numerically higher mean family size of 7.68 $(\mathrm{SD}=2.63)$. However, there was no statistically significant difference in mean family size between two groups. The Mean land size of the sample respondents was 2.48 hectares. Mean land size of market participant group was $2.16(\mathrm{SD}=1.38)$. By comparison, non-participant group was associated with numerically higher mean land size of 2.43 ha $(\mathrm{SD}=1.26)$; but the difference was not statistically significant. The enset products market participants have higher mean enset plantation than non-participants. In addition, participants walk lower mean market distance than non-participants. There was statistically significant difference in mean enset plantation and market distance between two groups at $1 \%$ and $5 \%$ level of significance, respectively (Table 2).

The sample was composed of both male and female-headed households. From the total sample respondents, 23.8 percent were femaleheaded households. From female-headed households, 91.7 percent were market participant and only 8.3 percent were non-participants. The difference in terms of sex of household head between the two groups was significant at $1 \%$ level of significance. From the total sample respondents, 56.4 percent had transport access and the remaining had no access. The difference in terms of transport access between the two groups was significant at $1 \%$ level of significance (Table 2).

From the total sample respondents, 55.4 percent had access to extension contact on enset production and marketing and the remaining had no access. The difference in terms of access to extension contact between the two groups was significant at $5 \%$ level of significance. 
Table 2. Descriptive result of sample respondents' characteristics.

\begin{tabular}{|c|c|c|c|c|c|c|c|}
\hline \multirow[t]{2}{*}{ Continuous variables } & \multicolumn{2}{|c|}{$\begin{array}{l}\text { Non-participants } \\
\qquad(\mathrm{N}=40)\end{array}$} & \multicolumn{2}{|c|}{$\begin{array}{l}\text { Participants } \\
(\mathrm{N}=61)\end{array}$} & \multirow[t]{2}{*}{ t- value } & \multicolumn{2}{|c|}{$\begin{array}{l}\text { Total sample } \\
(\mathrm{N}=101)\end{array}$} \\
\hline & Mean & $\mathrm{SD}$ & Mean & $\mathrm{SD}$ & & Mean & SD \\
\hline Age & 42.59 & 8.810 & 47.530 & 10.700 & $-1.980^{* *}$ & 45.720 & 10.220 \\
\hline Education (yrs.) & 1.37 & 2.190 & $4 \cdot 375$ & $3 \cdot 917$ & $-4.270^{* * *}$ & 3.278 & 3.674 \\
\hline Family size (nos.) & 7.68 & 2.636 & $7 \cdot 340$ & 2.154 & 0.687 & 7.460 & 2.334 \\
\hline Land size (ha) & 2.43 & 1.268 & 2.160 & 1.389 & 0.951 & 2.482 & 1.980 \\
\hline Livestock in TLU & 4.84 & 2.810 & 4.240 & 2.013 & 1.247 & 4.460 & 2.340 \\
\hline Enset plantation (timad) & 1.12 & 0.700 & 1.870 & 0.906 & $-4.100^{* * *}$ & 1.608 & 0.896 \\
\hline Market distance $(\mathrm{km})$ & 7.89 & 2.536 & 5.040 & 2.339 & $5 \cdot 720^{* * *}$ & 6.087 & 2.770 \\
\hline \multicolumn{8}{|l|}{ Discrete variables } \\
\hline Category & \multicolumn{2}{|l|}{ Percent } & \multicolumn{2}{|l|}{ Percent } & $\chi 2$ value & \multicolumn{2}{|l|}{ Percent } \\
\hline Sex (\% female) & 8.30 & & 91.70 & & $10.860^{* * *}$ & 23.80 & \\
\hline Transport access (\% yes) & 15.90 & & 84.10 & & $14.420^{* * *}$ & 56.40 & \\
\hline Access extension (\% yes) & 25.00 & & 75.00 & & $7 \cdot 328 * *$ & $55 \cdot 40$ & \\
\hline
\end{tabular}

*** and ${ }^{* *}$ represent significance at $1 \%$ and $5 \%$, respectively.

\section{Enset production status}

Sample respondents were asked to describe trend of enset plantation on their farms for the last five consecutive years prior to survey time (Fig. 1). The survey result showed that the average amount of land coverage by enset plantation per a farmer has been decreased from year of 2011 of mean of 1.71 timad to 1.61 timad of the year 201516 (8timad equivalent with a hectare). Different factors such as diseases, insect pests and vertebrates, lack of soil fertility, expansion of other crops, the use traditional production and processing techniques and lack of favorable market with attractive incentives were some of reasons respondents mentioned for decline of enset production. In addition, the focus given from government extension support was weak to encourage the enset crop cultivation. This adversely affected expansion of enset production and resulted in lost opportunity that the crop would contribute to the sustainability of food security and economic improvement of producers and other actors along the value chain. Some reports showed that due to these problems; enset production is seemingly limited to consumption purpose and this resulted in low participation of producers in the market (Alemayehu, 2018; Mohamed and Tariku, 2012).

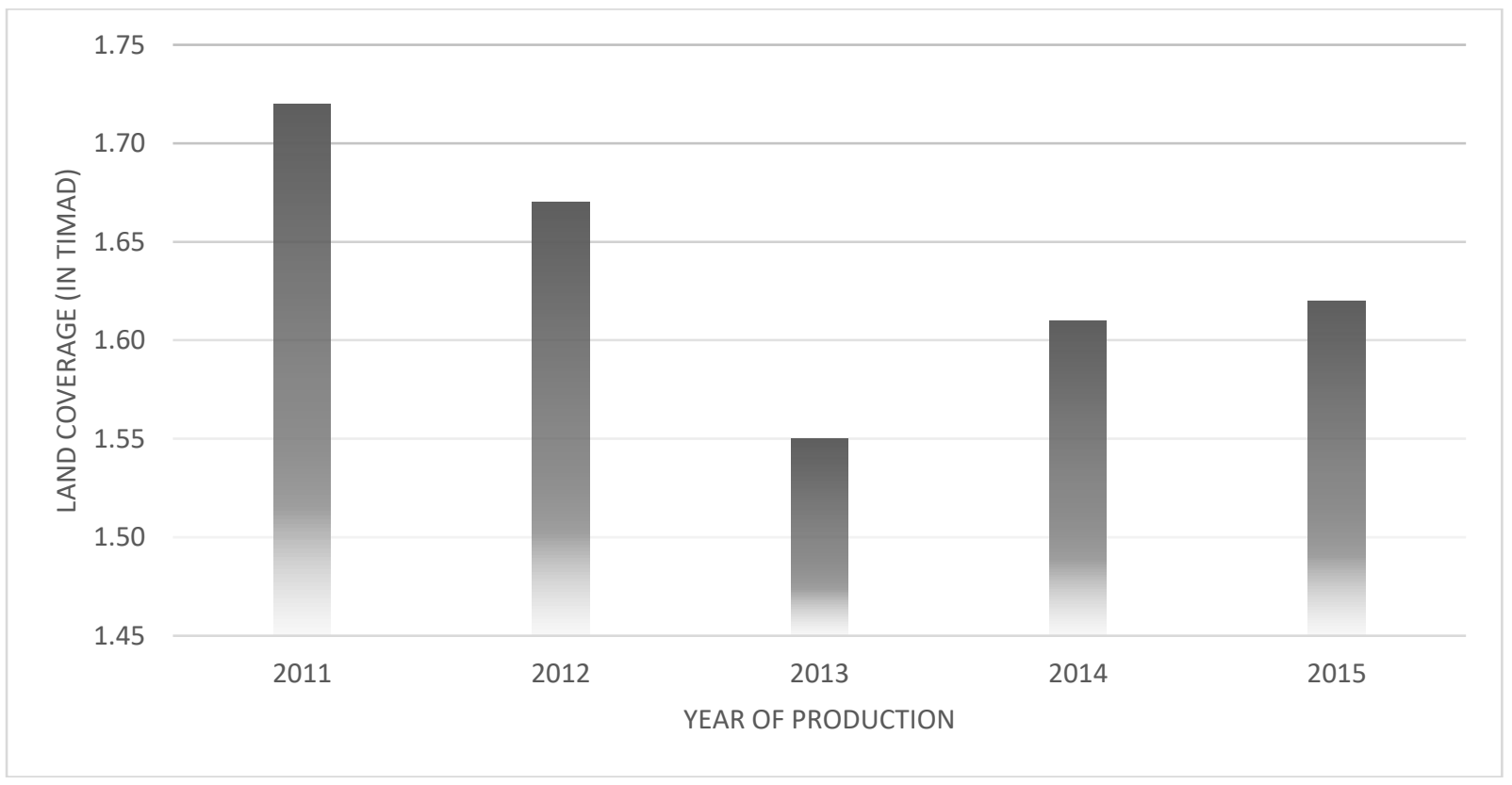

Fig. 1. Trend of enset plantation at household level (NB: 8 timads equivalent to a hectare). 


\section{Households' participation in sale of enset products}

The experience of farm households in making money from sale of the enset products was weak, as nearly 40 percent of sample respondents did not sale any enset product. The practice of enset products processing and marketing was mainly associated with women and males' participation at this stage was low, as most of male farmers have no knowledge about it. This condition affected the enset cultivation to be incompetent with other crops and resulted in low level of commercialization of enset production, despite the potential of the commodity to be additional source of income for farm households.

In this study, four available options that the households used were assessed. These options were; sale of enset products like Koch, bulla, fiber, and enset plant itself for other processors. Most of farm households who participated in sale of enset products sold kocho product and few farmers participated in sale of other products. Some of respondents showed the perception that; since extraction of bulla affects kocho quality, they did not process bulla separately. Due to this condition, only few farm households processed bulla and supplied to the market. The experience of households in extracting fiber product and using it for selling and other home service was weak.

Despite sale of enset plant could be used as other income source and some of male household heads better practiced it than other enset products, only few households used to sale the enset plants for other processors. From sample respondents who participated in sale of enset products in the year, 31 percent earned the amount less than 500 birr. Only 15 percent got the annual amount of more than 2000 birr and the rest of sample respondents earned the income amount between 500 up to 2000 birr (Table 3).

Table 3. Households income from sale of enset products.

\begin{tabular}{|l|c|c|}
\hline Income category (birr) & Frequency & Percent \\
\hline 0 & 40 & 39.6 \\
\hline $1-500$ & 19 & 18.8 \\
\hline $501-1000$ & 18 & 17.8 \\
\hline $101-2000$ & 15 & 14.9 \\
\hline$>2001$ & 9 & 8.9 \\
\hline Total & 101 & 100.0 \\
\hline
\end{tabular}

\section{Factors affecting households' market participation}

\section{Determinants of market participation}

From 11 explanatory variables expected to affect households' market participation, those variables, which found to be significant were, discussed under this section as follows (Table 4).

Sex of household head showed negative relation with market participation of enset products and significant at $5 \%$ level of significance. The model output showed that, if a dummy changed from being male to female-headed households, the probability of households' participation in marketing of enset products increases by $24.7 \%$ ceteris paribus. This might be due to the reason that, men usually own larger farmlands and have better practice of income diversification compared to women. In the area, enset was mainly produced for home consumption and in the condition that a household had alternative income sources, money making from sale of enset product was low. Due this condition, femaleheaded households were more market participant than male-headed households were. Similarly, Nuri et al. (2016) showed that the female-headed households are more market oriented than male headed and participate more in the marketing of enset products as kocho production and business is mostly gender specific.

Education level of household head affected market participation positively and significant at $1 \%$ level of significance. A one-year increase in education level of household head increases the probability of household's market participation by $6 \%$, keeping the other things remain constant. This might be because; being literate may put households in a relatively better position to gather, understand and realize information on production and marketing of enset products.

Livestock ownership affected market participation decision and significant at $10 \%$ level of significance. The result from the marginal effect revealed that, a unit increase in livestock ownership in TLU decreases the probability of household's market participation by $6 \%$, keeping the other things constant. This might be because; having more livestock owned creates better opportunity for diversified source of farm income as livestock is considered as liquid asset and households who have more livestock showed lower participation in sale of enset products. The finding is consistent with Rehima (2006) who showed farmers with more TLU tend to specialize in livestock production reducing the importance crop production as means of cash generation. 
However, it is contrary to Nuri et al. (2016) who showed positive relation between livestock ownership with enset production and marketing.

Distance from households' residence to the nearest market center is significant at $10 \%$ level of significance in negative relation with market participation decision. The result showed that a one-kilometer increase in distance from the nearest market decreases the probability of household's participation in the market by $4.6 \%$, assuming the other things remain constant. This is because farm households' residence far away from the market center coupled with the product nature like heavyweight per unit volume of the products discourages some farmers to supply enset product, like kocho, to the market. The finding is consistent with Tessema et al. (2017) and Nuri et al. (2016).

Area under enset plantation showed positive relation with market participation decision and significant at $1 \%$ level of significance. The model output showed that increase in area under enset plantation by one hectare increases the probability of households' participation in marketing of enset products by $87 \%$ ceteris paribus. This might be due to having more enset plantation covers households' consumption need, which allows the supply of surplus of harvest to the market and increases probability of market participation. This is in line with this Tessema et al. (2017) who showed positive relation between variables.

Transport access affected probability of market participation positively and significant at $1 \%$ level significance. The model output showed that if a household had transport access probability of market participation of enset products increases by $29.1 \%$. This is due to the product nature that heavyweight per unit volume of the product discouraged some farmers to supply kocho product to the market if they lacked transport access.

Table 4. First-stage probit estimation results of the determinants of market participation.

\begin{tabular}{|c|c|c|c|}
\hline Variables & Coefficient & Z & Marginal effect \\
\hline Sex & $-1.627^{* *}$ & -2.35 & -0.247 \\
\hline Age & 0.040 & 1.33 & 0.009 \\
\hline Education (yrs.) & $0.254^{* * *}$ & 2.87 & 0.060 \\
\hline Family size (nos.) & -0.153 & -1.42 & -0.036 \\
\hline Land size (ha) & 0.021 & 0.15 & 0.005 \\
\hline Livestock (TLU) & $-0.255^{*}$ & -1.80 & -0.060 \\
\hline Distance to market & $-0.198^{*}$ & -1.94 & -0.046 \\
\hline Enset plantation & $7 \cdot 991^{* * *}$ & 2.73 & 0.870 \\
\hline Extension contact & 0.654 & 1.41 & 0.159 \\
\hline Transport access & $1.344^{* * *}$ & 2.62 & 0.291 \\
\hline Market information & 2.016 & 1.34 & 0.206 \\
\hline Constant & 0.183 & 0.10 & \\
\hline \multicolumn{2}{|c|}{ Number of observations $=101$} & \multicolumn{2}{|l|}{ LR $\operatorname{chi} 2(11)=84.47$} \\
\hline \multicolumn{2}{|c|}{ Log likelihood $=-24.118$} & \multicolumn{2}{|l|}{ Prob $>$ chi2 $=0.0000$} \\
\hline \multicolumn{2}{|c|}{ Pseudo R2 = 0.636} & & \\
\hline
\end{tabular}

Factors affecting the amount of gross income from sale of enset products

From 10 explanatory variables expected to determine gross income earned from sale of enset products, five variables found to be significant in affecting (Table 5).

Education level of household heads affected the amount of gross income from sale of enset products positively and significant at $1 \%$ level of significance. For a one-year increase in education, the gross income from enset products increases by 90.45 birrs, ceteris paribus. This might be due to the reason that households who were educated tend to be more capable of exploring relevant information about enset production and marketing as they produce in better market-oriented way than household heads with lower education level.

Family size affected the amount of gross income from sale of enset products negatively and significant at $1 \%$ level of significance. For a unit increase in family size, the gross income from enset products decreases by 310.75 birrs, ceteris paribus. This negative relation was as a prior expectation because enset was mainly produced for home consumption and those households with higher family size supplied lower surplus amount and earned lower gross income from sale of enset products.

Land size of enset plantation affected the amount of gross income from sale of enset products positively and significant at $1 \%$ level of significance. For a one-hectare increase in 
plantation of enset, the gross income from sale of enset products increases by 561.10 birrs, ceteris paribus. Since the enset crop was considered cultivated as traditional staple food crop, the amount of land covered by enset plantation majorly determined surplus production and supply of enset plants to the market. Due to this reason, farmers who owned larger land size of enset plantation earned more income than those with small size of enset plantation. The finding is consistent with Tessema et al. (2017) who showed household with greater area under enset plantation will have more of matured enset to be harvested and the surplus of kocho and bulla supplied to the market.

Distance from households' residence to nearest market center showed negative relation and significant at $1 \%$ level of significance. The result showed that a one-kilometer increase in distance from the nearest market decreases the amount of income from sale of enset products by 175.05 birr, assuming the other things remain constant.
This is because farm households' residence far away from the market center and the heavyweight per unit volume of the product discourages some farmers to supply more enset product to the market than those living nearer to the market. Due to these conditions farm households residing near to market center supplied more products and earned more income than those living far. The finding is consistent with Tessema et al. (2017).

Transport access affected the amount of gross income from sale of enset products positively and significant at $10 \%$ level of significance. The model output showed that if a household had transport access the annual income from sale of enset products increases by 376.78 birr, assuming other things remain constant. This is due to the product nature that heavyweight per unit volume of the product discouraged some farmers to supply kocho product to the market if they lacked transport access.

Table 5. Results of the second-stage Heckman selection model.

\begin{tabular}{|c|c|c|c|}
\hline Variables & Coefficient & Standard error & $\mathrm{Z}$ \\
\hline Constant & 3551.590 & 702.306 & 5.06 \\
\hline Age & -3.774 & 6.228 & -0.610 \\
\hline Sex & -73.010 & 246.800 & -0.300 \\
\hline Education (yrs.) & $90.450^{* * *}$ & 28.626 & 3.160 \\
\hline Family size (nos.) & $-310.750^{* * *}$ & 52.136 & -5.960 \\
\hline Land size (ha) & 62.399 & 48.623 & 1.280 \\
\hline Livestock owned & -34.430 & 58.770 & -0.590 \\
\hline Enset plantation & $561.100^{* * *}$ & 118.700 & 4.730 \\
\hline Market distance & $-175.053^{* * *}$ & $47 \cdot 430$ & -3.690 \\
\hline Extension contact & 322.427 & 195.470 & 1.650 \\
\hline Transport access & $376.780^{*}$ & 215.080 & 1.750 \\
\hline Mills lambda $(\lambda)$ & $222.350^{* * *}$ & 65.450 & 3.397 \\
\hline Rho & 1.00 & & \\
\hline Sigma & 222.89 & & \\
\hline \multicolumn{2}{|c|}{ Number of observations $=101$} & \multicolumn{2}{|c|}{ Uncensored observation $=61$} \\
\hline \multicolumn{2}{|c|}{ Censored observations $=40$} & \multicolumn{2}{|c|}{ Wald chi2(10) $=239.86$} \\
\hline \multicolumn{2}{|c|}{ Log likelihood $=-514.7537$} & \multicolumn{2}{|c|}{ Prob $>$ chi2 $=0.0000$} \\
\hline
\end{tabular}

***, ** and * represent significance at $1 \%, 5 \%$ and $10 \%$, respectively.

\section{Conclusion and Recommendations}

Enset crop in the district is major indigenous root crop cultivated as traditional staple food crop. However, its area coverage at farm level has been decreasing for the last five years due to various reasons. Some of such factors include; diseases, insect pests and vertebrates, lack of soil fertility, expansion of other crops, the use traditional production and processing techniques and lack of favorable market with attractive price. Moreover, enset production is considered as mainly for consumption purpose and farmers' participation in marketing of enset products was weak for various reasons.
Econometric model result showed that sex, education level, livestock owned, distance from nearest market center, enset plantation, and transport access were found to be significant in influencing the probability of market participation decision. In addition, education level, family size, distance from the nearest market center, enset plantation, and transport access affected the amount of gross income from sale of enset products.

The problems related with harvesting, processing and marketing of enset products was its limitation to traditional equipment and methods. Women faced lack of improved harvesting and processing technology in the area and that affected their capacity and performance. 
Therefore, it would be better if district agricultural office in collaboration with research centers and other concerned bodies work on introduction, demonstration and widely dissemination of improved technology around enset processing and marketing in the area.

Even though enset production was considered as mainly for consumption purpose in the district, it could also be potential source of farm income for producers. Therefore, different stakeholders' involvement is needed to establish marketoriented production of enset crop trough capacitating farmers for better production and market supply to have higher amount of income from the commodity and assuring provision of considerable income diversification source.

The existing marketing system and lack of market information coupled with awareness problems made most of male-headed households to stay far away from participation in marketing of enset products. To have increased participation of farmers and make the enset crop as additional source of farm income for producers, establishing favorable market, market promotion and dissemination of market information for producers is needed.

\section{References}

Alemayehu, A.A. 2018. The Role of Women in Enset Market Chain the Cause of Dawuro Zone, Southern Nations Nationalities and Peoples Regional State, Ethiopia. Int. J. Curr. Res. Aca. Rev. 6(4): 36-47. https://doi.org/10.20546/ijcrar.2018.604.006

Belachew, G., Aklilu, A., Bewuketu, H. and Habtamu, K. 2017. Indigenous Knowledge of Enset [Ensete ventricosum (Welw.) Cheesman] Cultivation and Management Practice by Shekicho People, Southwest Ethiopia. J. Plant Sci. 5(1): 6- 18. https://doi.org/10.11648/j.jps.20170501.12

Birmeta, G., Nybom, H. and Bekele, E. 2004. Distinction between wild and cultivated enset (Ensete ventricosum) gene pools in Ethiopia using RAPD markers. Herediats. 140: 139148.

https://doi.org/10.1111/j.1601-5223.2004.01792.x

CDOARD. 2015. Report on socio economic profile and background information of the district, Chena District Office of Rural Development, Ethiopia. 27p. Accessed 14 March 2015.

Cragg, J. 1971. Some Statistical Models for Limited Dependent Variables with Application to the Demand for Durable Goods, Econometrica. 39: 829-844. https://doi.org/10.2307/1909582

CSA. 2015. Agricultural sample survey of Ethiopia. Report on area and production of major cops. Central Statistical Authority, Addis Ababa, Ethiopia. 128p.
Endalamaw, T.B., Lindner, A. and Pretzsch, J. 2013. Indicators and determinants of smallscale bamboo commercialization in Ethiopia. Forests. 4(3): 710-729.

FAO. 2015. Statistical Pocket Book 2015. Food and Agriculture Organization, Rome.

Greene, W.H. 2003. Econometric analysis, Volume 3. Prentice Hall Upper Saddle River, New Jersey. 828p.

Kassa, T., Jema, H. and Bosena, T. 2018. Factors affecting market supply of honey in Chena district, Kaffa zone, Southern Ethiopia. J. Dev. Agril. Econ. 10(3): 99-109.

Kifle, B., Mebratu, G. and Kumlachew, A. 2015. Integrated management of common bacterial blight (Xanthomonas axonopodispv. Phaseoli) of common bean (Phaseolus vulgaries) in Chena district of Kaffa zone, Southwest Ethiopia. Malaysia J. Med. Biol. Res. 2(2): 147-152.

Mohamed, Y. and Tariku, H. (eds.). 2012. Enset Research and Development Experiences in Ethiopia. In: Proceedings of Enset National Workshop, 19-20 August 2010, Wolkite, Ethiopia.

NBE. 2014-15. Annual Report of Year 2014-15. National Bank of Ethiopia. 78p.

Nuri, L, Jema, H., Endrias, G. and Lemma, Z. 2016. Determinants of status and extent of market participation among kocho Producers in Hadiya Zone, Southern Ethiopia. Int. J. Agril. Res. Rev. 4(2): 476485.

Rehima, M. 2006. Analysis of red pepper marketing: The case of Alaba and Siltie in SNNPRS of Ethiopia. M.Sc thesis presented to the School of Graduate Studies, Haramaya University, Oromia, Ethiopia. $105 p$.

Tessema, E., Bosena, T. and Lemma, Z. 2017. Determinants of market participation of Enset (Ensete ventricosum) Farmers: The Case of Doyogena District, SNNPR, Ethiopia. J. Econ. Sustain. Dev. 8(15): 8594.

Tobin, J. 1958. Estimation of Relationships for Limited

Variables. Econometrica. 26(1): 24-36. https://doi.org/10.2307/1907382

Tsehaye, Y. and Kebebew, F. 2006. Diversity and cultural use of enset [Ensete ventricosum (Welw.) Cheesman] in Bonga in-situ Conservation Site, Ethiopia, Ethnobot. Res. Appl. 4: 147- 157. https://doi.org/10.17348/era.4.0.147-158

Wooldridge, J.M. 2002. Econometric Analysis of Cross Section and Panel Data. Cambridge, MA: MIT Press.

Yemataw, Z., Mekonen, A., Chala, A., Tesfaye, K., Mekonen, K., Studholme, D.J. and Sharma, K. 2017. Farmers' knowledge and perception of enset Xanthomonas wilt in southern Ethiopia. Agric. Food Secur. 6: 62. https://doi.org/10.1186/s40066-017-0146-0 